\title{
Modelling the effect of catena position and hydrology on soil chemical weathering
}

Vanesa García-Gamero ${ }^{1}$, Tom Vanwalleghem ${ }^{1}$, Adolfo Peña ${ }^{2}$, Andrea Román-Sánchez ${ }^{3}$, Peter A. Finke

${ }^{1}$ Department of Agronomy, University of Córdoba, Da Vinci building, Madrid km 396 Rd., 14071 Córdoba, Spain

$5 \quad{ }^{2}$ Department of Rural Engineering, Civil Constructions and Engineering Projects, University of Córdoba, Da Vinci building, Madrid km 396 Rd., 14071 Córdoba, Spain.

${ }^{3}$ Department of Forest Ecology, The Silva Tarouca Research Institute, Lidická 25/27,602 00 Brno, Czech Republic.

${ }^{4}$ Department of Environment, University of Ghent, Coupure Links 653, 9000 Ghent, Belgium.

Correspondence to: Vanesa García-Gamero (g02gagav@uco.es)

10 Abstract. The sensitivity of chemical weathering to climatic and erosional forcing is well established at regional scales. However, soil formation is known to vary strongly along catenas where topography, hydrology, and vegetation cause differences in soil properties and possibly chemical weathering. This study applies the SoilGen model to evaluate the link between topographic position and hydrology with the chemical weathering of soil profiles on a north-south catena in southern Spain.

15 Pedogenesis was measured and simulated in seven selected locations over a 20000-year period. A good correspondence between simulated and measured chemical depletion fraction $(\mathrm{CDF})$ was obtained $\left(\mathrm{R}^{2}=0.47\right)$. An important variation in $\mathrm{CDF}$ values along the catena was observed, although the position along the catena alone, nor by the slope gradient, explained this variation well. However, the hydrological variables explained the observed trends better. A positive trend between CDF data and soil moisture and infiltration and a negative trend with water residence time was found.

20 The model sensitivity was evaluated with a large precipitation gradient (200-1200 mm yr$\left.{ }^{-1}\right)$. While a marked depth gradient was obtained for $\mathrm{CDF}$ with precipitation up to $800 \mathrm{~mm} \mathrm{yr}^{-1}$, a uniform depth distribution was obtained with precipitation above $800 \mathrm{~mm} \mathrm{yr}^{-1}$. The basic pattern for the response of chemical weathering to precipitation is a unimodal curve, with a maximum around a mean annual precipitation value of $800 \mathrm{~mm} \mathrm{yr}^{-1}$. Interestingly, this corroborates similar findings on the relation of other soil properties to precipitation and should be explored in further research.

\section{Introduction}

The spatial variability of soil properties is conditioned by the five main soil forming factors: Climate, Organisms, Relief, Parent material, and Time (Jenny, 1941). Differences in the spatial and temporal distribution of these factors cause both long and short-scale spatial heterogeneity. In recent years, different soil formation models have been developed that explain the landscape or long-scale soil variability well. Such models range from simple mechanistic soil depth models ( Minasny \& 
https://doi.org/10.5194/soil-2021-78

Preprint. Discussion started: 17 August 2021

(c) Author(s) 2021. CC BY 4.0 License.

McBratney, 2001) to more complex models that link different soil forming processes and erosion-deposition, for example, MILESD or LORICA (Temme and Vanwalleghem, 2016; Vanwalleghem et al., 2013).

However, the short-scale variability, or catena effect, has received much less attention. The interlocking of specific soil and vegetation associations at different landscape positions was first described by Milne (1935) and is widely used in soil science (Borden et al., 2020). The soil catena can be understood from the retention and movement of water and chemical elements linked to topography and vegetation (Reuter and Bell, 2001). Recently, Ferrier and Perron (2020) constructed a numerical model for the coevolution of topography, soils and soil mineralogy that allowed them to conclude that the hillslope scale has a critical importance in the response of chemical weathering rates to changes in tectonics and climate. However, most existing soil formation models do not account for hydrology, nor for chemical weathering reactions. For example, the models marm3D

40 (Cohen et al., 2010) and SSSPAM (Welivitiya et al., 2019) linked landscape and pedogenesis processes for catena spatial scales, but while they represent physical weathering and armouring well, they did not account for chemical weathering. At present, the only models of soil genesis with the capability of simulating water flow, physical and chemical weathering and chemical equilibriums are one-dimensional, for example, SoilGen (Opolot et al., 2015). In spite of this limitation, such models have been applied successfully at the landscape scale, by modelling the different landscape positions independently. Finke

45 (2012) for example modelled 3 soil profiles on different topographic positions in the loess belt of Belgium. Finke et al. (2013) modelled the spatial variation of soil horizons at 108 locations in a 1329 ha large forest area in the same loess belt region. However, there is still need to further test these one-dimensional models against field data from different environments, and especially, to test their capabilities to model chemical weathering.

Field studies have shown the importance of chemical weathering in the overall soil formation processes, and have shown that 50 physical erosion and chemical weathering are tightly coupled (Riebe et al., 2004) as the main processes in eroding environments. The combination of these processes determines the total denudation rate (Riebe et al., 2001). The contribution of chemical weathering (W) to the total denudation rate (D), W/D, can be inferred by comparing the concentration of immobile elements in soil and bedrock, through the chemical depletion fraction (CDF) (Riebe et al., 2001).

There is an ongoing debate in the scientific community to whether chemical weathering is limited by physical erosion and the 55 supply of fresh particles (e.g Larsen et al., 2014) or whether it is limited by reaction kinetics (e.g. Gabet \& Mudd, 2009). Generally, it is assumed from models and field studies in different environments that soil weathering is supply-limited when erosion rates are low, and kinetically limited when erosion rates increase, as the shorter soil residence times imply that minerals do not stay in the soil long enough to become fully weathered. Larsen et al. (2014) compiled data from the New Zealand Alps, among the world's most rapidly eroding mountain areas, and still found a positive relation between physical erosion rates and 60 chemical weathering, indicating supply-limited conditions. On the other hand, is well established that climate and specifically water availability is also an important factor affecting chemical weathering rates (e.g. Maher, 2011). Climatic factors affect significantly because of the dependency of the chemical weathering types of water to drive the chemical alteration of rocks 
https://doi.org/10.5194/soil-2021-78

Preprint. Discussion started: 17 August 2021

(c) Author(s) 2021. CC BY 4.0 License.

(c) (i)

and are potentially accelerated by high temperatures because it affects the kinetics reactions and solubilities (Duarte et al., 2018). Schoonejans et al. (2016) confirmed the significant relation of chemical weathering to rainfall, by measuring CDF

65 along a climatic gradient in a semiarid environment in the Southern Betic Cordillera (Spain). Whereas much of soil weathering research has focused much on the critical control of physical erosion rates on chemical weathering, more recent research by Calabrese and Porporato (2020) stresses the control of wetness. They suggest that water-limited environments are kinetically limited. Globally, they calculate $61 \%$ of the land to be kinetically-limited, while only $1 \%$ would be supply-limited. If their findings can be confirmed, it would imply that climatic conditions and soil hydrology are much more important than previously

70 assumed. In any case, these authors point out that the factors affecting chemical weathering need to further be disentangled (Calabrese and Porporato, 2020).

However, the relation between weathering and water availability is not limited to precipitation and evapotranspiration but is also related to other factors such as infiltration or topography, and even vegetation. Along a catena, the hydrology is considerably different depending on the position (Chadwick et al., 2013). Brantley et al. (2017) developed a conceptual model

75 to link chemical weathering reaction fronts to hillslope hydrology. Knowing how difficult it is for hydrologists to select models, they developed a conceptual model to relate reaction fronts with water flow inside hillslopes, exemplified with field data for shale, granite, and diabase. Riebe et al. (2004) made measurements on 42 study sites with highly variable climate regimes and they showed that the degree of chemical depletion increases systematically with temperature and precipitation. Dahlgren et al. (1997) in their work developed along an elevational transect in the Sierra Nevada in California (USA) found the maximum 80 degree of chemical weathering with intermediate levels of precipitation and temperature. Dixon et al. (2016), along $60 \mathrm{~km}$ of a north-south toposequence in the Waitaki Valley in the South Island of New Zealand, marked with an important precipitation gradient, identified a pedogenic threshold at mean annual precipitation of $\sim 800 \mathrm{~mm} \mathrm{yr}^{-1}$. Samouëlian and Cornu (2008) pointed out the role of water in soil formation and how the soil moisture regime variation and its influence on soil formation processes were not included in several models. Indeed, the soil moisture dynamics related to the topographical position has been studied

85 by several authors, such as Salve et al. (2012), who have monitored this and other variables for 4 years with multiple measurement devices on a hillslope in coastal Mendocino County, in northern California, USA. Mudd \& Furbish (2006) presented a hillslope model that couples the evolution of topography and soil thickness by using immobile minerals. They assessed the importance of hydrology on the rate of chemical weathering in hillslope soils. Yoo et al. (2007) developed a model that integrated the Riebe et al. (2001) method and tested it with experimental data from a watershed in south-eastern Australia

90 for simultaneously quantifying the rates of chemical weathering and soil transport as a function of hillslope position. Afterward, this work was expanded by Yoo et al. (2009). They quantified soil chemical weathering rates along a grass-covered hillslope in the Tennessee Valley in Coastal California (USA) and began to elucidate the mechanisms that control the topographical dependence on chemical weathering being the next step includes hydrology into the model. Langston et al. (2011) explored the role of hydrology in saprolite formation through 2-D numerical calculations on two idealized slopes, north (NFS) and 95 south-facing (SFS), respectively, in the Boulder Creek watershed, Colorado (USA). Highlighting the importance of time and 
hillslope aspect in the formation of the saprolite and the need to couple hydrologic models with reactive-transport models to better understand the distribution of chemical weathering intensity. Braun et al.(2016) presented a model for the formation of regolith on geological timescales by chemical weathering, pointing out that this process has long been neglected in favor of hillslopes physical processes by geomorphologists, this process also being the mechanism that leads to the formation of aquifers from the unweathered bedrock (Lachassagne and Wyns, 2011). Previously, the weathering zone had been considered the one located over the groundwater level. However, Lebedeva \& Brantley (2020) formulated a simplified weathering model to explore relationships between weathering and the water table taking into account the unsaturated and the saturated zone. Because of the need to couple hydrology with chemical weathering to understand spatial variability in soil formation, this study applied the SoilGen model ( Finke \& Hutson, 2008) to different pedons and different hydrological conditions along a catena in a Mediterranean catchment in southern Spain. Finke \& Hutson (2008) created the SoilGen model to reconstruct soil development based on present knowledge. It is a 1-D solute transport extended with various soil development processes such as physical and chemical weathering, clay migration, cycles of various elements including that of $\mathrm{C}$ and bioturbation, where soil forming-factors (climate, organisms, relief, parent material, and time) serve as initial- and boundary conditions to recreate soil formation over various parent materials. The specific objectives were: (i) to evaluate differences in simulated soil development between two opposing, north-south facing, hillslopes, from 20000 years before present to present; (ii) to relate soil development to differences in hydrological dynamics and (iii) to evaluate, through sensitivity analysis, the capability of the SoilGen model to simulate soil development in a Mediterranean catchment in granitic parent material.

\section{Materials and methods}

\subsection{Study site}

115 The study site is located in a semi-natural area of oak-woodland savanna or 'dehesa' (a traditional Mediterranean silvopastoral system, Olea \& San Miguel-Ayanz, 2006) in Cardeña, within the Sierra Morena mountain range, in southern Spain $\left(38.20^{\circ}\right.$ N; 4. $17^{\circ} \mathrm{W}, 700 \mathrm{~m}$ a.m.s.1.) (Fig.1). Seven locations were chosen along a north-south catena, each separated at a distance between 50 and $100 \mathrm{~m}$ on two opposite hillslopes. A summary of the characteristics of the locations is given in Table 1. A full soil profile description was made at each point, and soil samples were taken for chemical analysis up till the bedrock. Next, five

120 soil moisture sensors were installed in each profile at different depths between 5 and $45 \mathrm{~cm}$. For details on the soil hydrology dynamics, see García-Gamero et al. (2021).

According to the Köppen-Geiger climate classification (Peel et al., 2007), the area has a continental Mediterranean climate (BSk) with an average annual rainfall of $878 \mathrm{~mm}$ (1981-2010), with cold winters and long, dry summers. The mean annual air 
https://doi.org/10.5194/soil-2021-78

Preprint. Discussion started: 17 August 2021

(c) Author(s) 2021. CC BY 4.0 License.

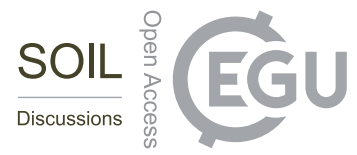

temperature is $15.3^{\circ} \mathrm{C}$, the coldest month is January, with a mean monthly temperature of $7^{\circ} \mathrm{C}$, and the hottest July, with a mean monthly temperature of $25.4^{\circ} \mathrm{C}$ (Carpintero et al., 2020).

Soils in the catchment are derived from Los Pedroches batholith parent material, which consists of a main granodioritic unit, several granite plutons, and an important acid-to-basic dike complex (Carracedo et al., 2009). These fall into three classifications: Regosols, Leptosols, and Cambisols according to the FAO-Unesco World Reference Base (IUSS Working Group WRB, 2015). The texture class ranges from sand to sandy loam with a soil depth generally ranging between $0.5 \mathrm{~m}$ along

130 the south aspect part of the transect and $1.0 \mathrm{~m}$ along the northern part of the transect ( Román-Sánchez et al., 2018), according to soil observations.

Vegetation in a dehesa includes sparse trees, holm and cork oaks, shrubs, retama, and annual grasses such as Lolium sp., Bromus sp., and Trifolium sp., with maximum production in spring and a non-vegetative period in summer (Olea and San Miguel-Ayanz, 2006).

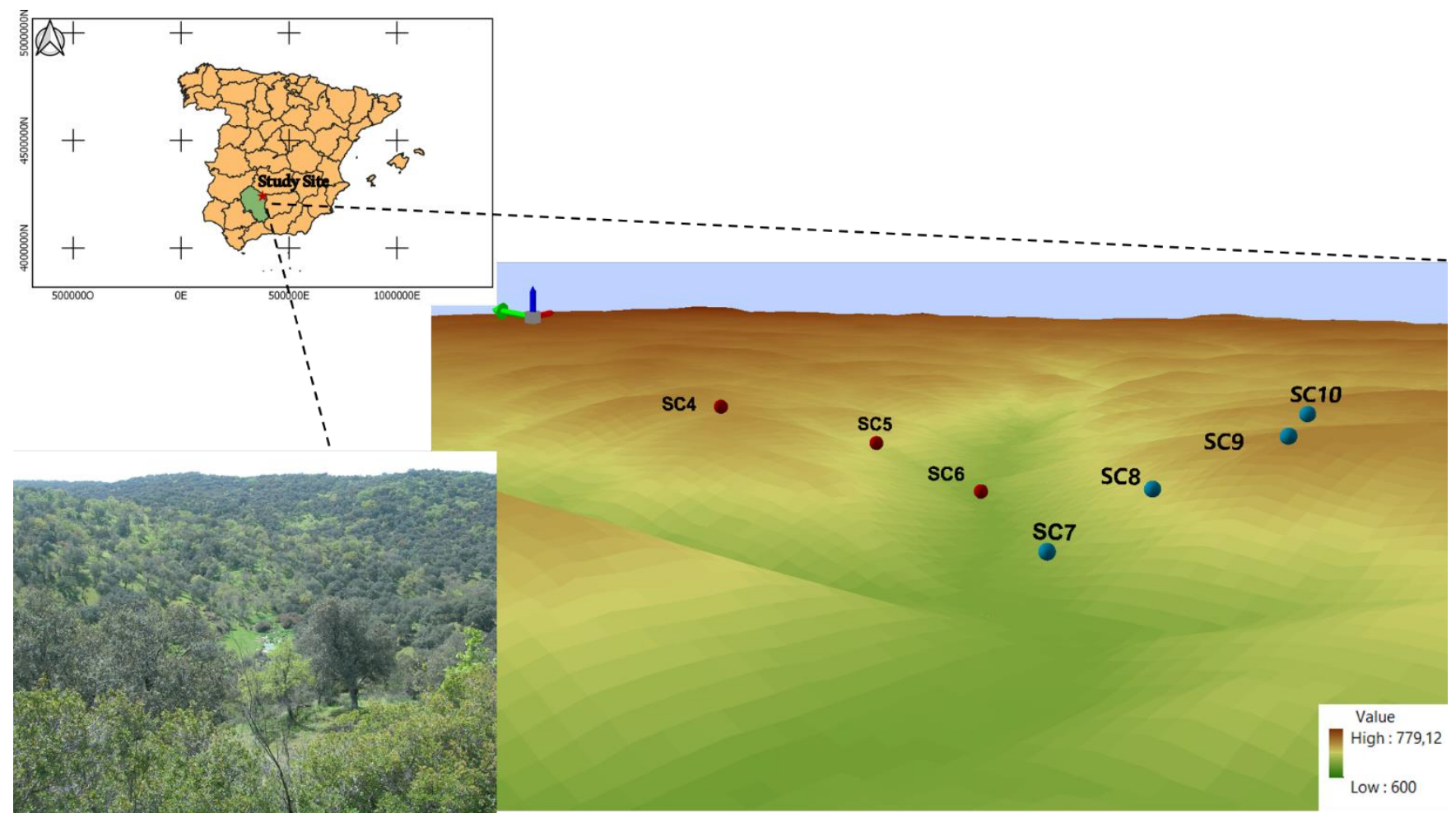

Figure 1: General location map of the study area and a detailed terrain map showing the location of the seven analyzed soil profiles along the catena with two opposing north-south facing slopes (respectively NFS and SFS, blue and red dots). The inset photo shows a landscape view of the study area. Note the green arrow indicates the north. 
https://doi.org/10.5194/soil-2021-78

Preprint. Discussion started: 17 August 2021

(c) Author(s) 2021. CC BY 4.0 License.

(c) (i)

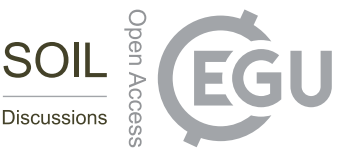

140 Table 1. Characteristics of the seven locations (SC4-SC10) in the study site.

\begin{tabular}{lccccccc}
\hline & SC4 & SC5 & SC6 & SC7 & SC8 & SC9 & SC10 \\
\hline $\begin{array}{l}\text { Latitude } \\
\text { Slope }\left(^{\circ}\right)\end{array}$ & $38^{\circ} \mathrm{N}$ & $38^{\circ} \mathrm{N}$ & $38^{\circ} \mathrm{N}$ & $38^{\circ} \mathrm{N}$ & $38^{\circ} \mathrm{N}$ & $38^{\circ} \mathrm{N}$ & $38^{\circ} \mathrm{N}$ \\
$\begin{array}{l}\text { Upslope } \\
\text { bearing }\left({ }^{\circ}\right)\end{array}$ & 4 & 20 & 14 & 4 & 27 & 19 & 2 \\
$\begin{array}{l}\text { Downwind } \\
\text { bearing }\left({ }^{\circ}\right)\end{array}$ & 35 & 27 & 40 & 55 & 61 & 66 & 53 \\
\hline
\end{tabular}

\subsection{Testing of modelled soil hydrology}

SoilGen simulates over millennium scales the flow of water, heat, solutes, and $\mathrm{CO}_{2}$ in unconsolidated geomaterials by numerically solving partial differential equations (the Richards equation, heat flow equation, advection-dispersion equation,

145 and C02-diffusion equation respectively) (Finke \& Hutson, 2008).

Given the importance of water fluxes for soil formation in general and chemical weathering specifically, the model was tested for its ability to simulate the soil moisture dynamics accurately. For this, the current soil profile characteristics in 7 locations were used to run the model over a two-year period in which soil moisture was measured, i.e., 2016 and 2017. The soil moisture sensors started to collect data at the end of 2016 so for the first part of the year the simulations were adapted using precipitation

150 and evapotranspiration data from 2017. This could be considered a spin-up (because the initial soil moisture profile was not known).

To account for interception by vegetation, we reduced the daily precipitation by a fixed value of $2 \mathrm{~mm}$, as suggested by Laio et al. (2001). These changes resulted in a reduction of the measured precipitation during the calibration period of $718.68 \mathrm{~mm}$ to $525.40 \mathrm{~mm}$.

155 Model-to-data correspondence was tested by comparing simulated values with measured values of soil moisture content, by the $\mathrm{R}^{2}$ and the Nash-Sutcliffe Efficiency (NSE).

\subsection{Model Inputs}

The tested model was then run at the seven soil profile location for long-term simulations (20000 years). This simulation period represents the residence time of the soil profile based on field measurements with Optically-Stimulated Luminescence (Román-

160 Sánchez et al., 2019). Table 2 summarizes the main model parameters and initial values. Figure 2 depicts the temporal variation of boundary inputs if time series were reconstructed over the simulation period. In order to represent correctly the 
https://doi.org/10.5194/soil-2021-78

Preprint. Discussion started: 17 August 2021

(c) Author(s) 2021. CC BY 4.0 License.

(c) (1)

Mediterranean climate variability, the climate data reconstructions were obtained by combining a mean temperature, precipitation, or evapotranspiration from the pollen-based dataset by Davis et al.(2003), with the observed year-to-year variability of modern weather observations.

165 Table 2. Inputs for the SoilGen Model.

\begin{tabular}{|c|c|c|c|c|c|c|}
\hline Group & $\begin{array}{l}\text { Input Variable or } \\
\text { Parameter }\end{array}$ & Dimensions & $\begin{array}{l}\text { As Initial } \\
\text { Condition }\end{array}$ & $\begin{array}{l}\text { Time } \\
\text { series, in } \\
\text { Typical } \\
\text { Year }\end{array}$ & $\begin{array}{l}\text { Time } \\
\text { Series, } \\
\text { Annual }\end{array}$ & $\begin{array}{l}\text { Source for Data and/or } \\
\text { Method }\end{array}$ \\
\hline \multirow[t]{3}{*}{ Climate } & Temperature & ${ }^{\circ} \mathrm{C}$ & Yes & $\begin{array}{l}\text { Weekly } \\
\text { average and } \\
\text { daily } \\
\text { amplitude }\end{array}$ & $\begin{array}{l}\text { January } \\
\text { and July } \\
\text { averages }\end{array}$ & $\begin{array}{l}\text { Davis et al., 2003; } \\
\text { Cardeña weather data }\end{array}$ \\
\hline & Precipitation & $\mathrm{mm}$ & - & $\begin{array}{l}\text { Daily depth, } \\
\text { intensity, } \\
\text { and } \\
\text { chemical } \\
\text { composition } \\
\text { of rain }\end{array}$ & $\begin{array}{l}\text { Annual } \\
\text { sum }\end{array}$ & $\begin{array}{l}\text { Davis et al., 2003; } \\
\text { Cardeña weather data }\end{array}$ \\
\hline & $\begin{array}{l}\text { Potential } \\
\text { evapotranspiration }\end{array}$ & $\mathrm{mm}$ & - & $\begin{array}{l}\text { Weekly } \\
\text { total }\end{array}$ & $\begin{array}{l}\text { Annual } \\
\text { sum }\end{array}$ & $\begin{array}{l}\text { Hargreaves \& Samani, } \\
1985\end{array}$ \\
\hline \multirow[t]{2}{*}{ Organisms } & Vegetation type & - & - & - & $\begin{array}{l}\text { Vegetation } \\
\text { type, } \\
\text { rooting } \\
\text { depth, and } \\
\mathrm{C} \text { input as } \\
\text { litter }\end{array}$ & $\begin{array}{l}\text { Olea \& San Miguel- } \\
\text { Ayanz, } \\
\text { Unpublished data from } \\
\text { Santa Clotilde 'dehesa' }\end{array}$ \\
\hline & Bioturbation & $\mathrm{Mg} \mathrm{ha}^{-1} \mathrm{yr}^{-1}$ & - & - & $\begin{array}{l}\text { Yearly } \\
\text { depth } \\
\text { distribution }\end{array}$ & Gobat et al., 1998, p. 122 \\
\hline Relief & Slope angle & degree & Yes & & & $\begin{array}{l}\text { DEM; (García-Gamero } \\
\text { et al., 2021) }\end{array}$ \\
\hline
\end{tabular}


https://doi.org/10.5194/soil-2021-78

Preprint. Discussion started: 17 August 2021

(c) Author(s) 2021. CC BY 4.0 License.

\begin{tabular}{|c|c|c|c|c|}
\hline & Slope aspect & degree & Yes & $\begin{array}{l}\text { DEM; (García-Gamero } \\
\text { et al., 2021) }\end{array}$ \\
\hline & Wind direction & degree & Yes & Cardeña weather data \\
\hline \multirow{10}{*}{$\begin{array}{l}\text { Parent } \\
\text { material }\end{array}$} & Clay/Silt/Sand & Mass \% & Yes & Granite: 7.0/17.4/75.6 \\
\hline & & & & $\begin{array}{l}\text { Unpublished data from } \\
\text { analyzed horizons in } \\
\text { Santa Clotilde 'dehesa' }\end{array}$ \\
\hline & $\mathrm{OC}$ & Mass \% & Yes & $0.17 \%$ \\
\hline & $\mathrm{Ca}, \mathrm{Mg}, \mathrm{Na}, \mathrm{K}, \mathrm{Al}$, & & Yes & Unpublished data \\
\hline & $\begin{array}{l}\mathrm{SO}_{4}, \quad \mathrm{Cl}, \\
\text { Alkalinity } \\
\text { solution }\end{array}$ & $\mathrm{mmol} \mathrm{dm}^{-3}$ & & \\
\hline & $\begin{array}{l}\mathrm{Ca}, \mathrm{Mg}, \mathrm{Na}, \mathrm{K}, \mathrm{Al} \text {, } \\
\mathrm{H} \text { on exchange } \\
\text { complex and CEC }\end{array}$ & $\mathrm{mmol}+\mathrm{kg}^{-1}$ & Yes & $\begin{array}{l}\text { Unpublished data from } \\
\text { analyzed horizons in } \\
\text { Santa Clotilde 'dehesa' }\end{array}$ \\
\hline & $\mathrm{CaCO}_{3} / \mathrm{CaSO}_{4}$ & Mass $\%$ & Yes & $0.01 / 0 \%$ \\
\hline & & & & $\begin{array}{l}\text { Unpublished data from } \\
\text { analyzed horizons in } \\
\text { Santa Clotilde 'dehesa' }\end{array}$ \\
\hline & $\begin{array}{l}\text { Gapon exchange } \\
\text { coefficients }\end{array}$ & $\left.(\mathrm{mol} \mathrm{dm})^{-3}\right)^{1 / \mathrm{n}-1 / \mathrm{m}}$ & Yes & $\begin{array}{l}\text { De Vries and } \\
\text { Posch (2003) }\end{array}$ \\
\hline & $\begin{array}{l}\mathrm{Ca}, \mathrm{Mg}, \mathrm{Na}, \mathrm{K}, \mathrm{Al} \\
\text { in primary } \\
\text { minerals }\end{array}$ & $\mathrm{mol}^{+} \mathrm{kg}^{-1}$ & Yes & $\begin{array}{l}\text { Unpublished data from } \\
\text { Santa Clotilde 'dehesa' }\end{array}$ \\
\hline
\end{tabular}



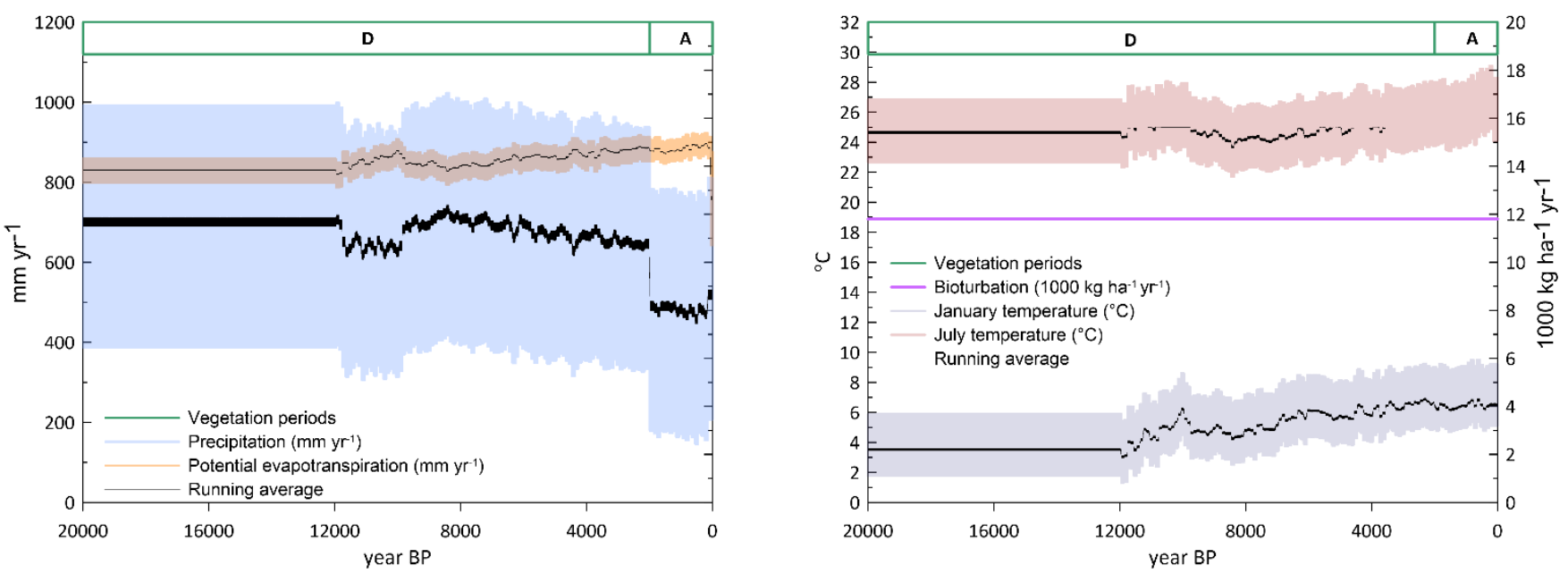

Figure 2: Boundary conditions for the soil modelling, representing reconstructed climate and vegetation change over the last 20000 years, the left panel shows precipitation and evapotranspiration, the right panel shows temperature. The bandwidth indicates the year-to-year variability in the climate data, and the bold, black line indicates the 25 year running average. $A=A g r i c u l t u r e, D=$ Deciduous wood.

\subsection{Chemical weathering}

Chemical depletion fraction (CDF), expressing the total fractional mass lost to chemical weathering, is a widely used indicator of the degree of chemical weathering of a soil profile (Dixon et al., 2009; Riebe et al., 2001):

$$
C D F=1-\frac{Z_{r}^{R O C K}}{Z_{r}^{S O I L}}
$$

where $\mathrm{Zr}^{\mathrm{ROCK}}$ is the $\mathrm{Zr}$ concentration in the bedrock and $\mathrm{Zr}{ }^{\mathrm{SOlL}}$ is the $\mathrm{Zr}$ concentration in the soil. CDF values close to zero indicate the absence of weathering, as the $\mathrm{Zr}$ concentration of the soil is equal to that of the parent material. Values closer to 1 indicate higher chemical weathering, as the weathering of mobile elements results in a relative increase of the immobile $\mathrm{Zr}$ in the soil profile (Yoo et al., 2011).

$180 \mathrm{CDF}$ values were measured in the field by sampling each soil profile and comparing it to the minimum value registered in the soil profile (Table 3). The chemical analyzes were performed on a PHILIPS model PW 2404 wavelength-based X-ray fluorescence spectrometer (WDS) with a $4 \mathrm{~kW}$ rhodium anode tube. For the determination of trace elements, the Pro-trace program of the PANalytical company was used, based on calibration curves that include both geological patterns and reference patterns of the program itself. The samples were prepared in a tablet pressed at 40 tons for two minutes. The amount of sample used was $10 \mathrm{~g}$ mixed with a solution of Elvacite, in a proportion of $10 \mathrm{~g}$ of sample with $4 \mathrm{ml}$ of solution.

The SoilGen model was then used to model the measured CDF values, assuming one completely inert (0-weathering rate) mineral, and to explore the sensitivity of the CDF to variations of precipitation. The effect on model results of a marked gradient of precipitation, between 200 and $1200 \mathrm{~mm}$, has been evaluated at the SC10 location, because of its position at the hilltop, representative of the larger plateau area. 
https://doi.org/10.5194/soil-2021-78

Preprint. Discussion started: 17 August 2021

(c) Author(s) 2021. CC BY 4.0 License.

(c) (i)

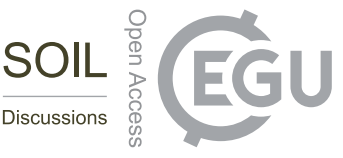

190 We conducted the performance evaluation by selecting various statistical indicators to conduct a quantitative analysis: the fraction of predictions within a factor or two (FAC2), the fractional bias (FB), the root mean square error (RMSE), and the normalized mean square error (NMSE).

Table 3. Chemical composition of the seven soil profiles (SC4-SC7). Values are averaged over the total soil profile depth. Mean measured Chemical Depletion Fraction, CDF.

\begin{tabular}{|c|c|c|c|c|c|c|c|c|c|c|c|c|c|c|}
\hline Location & $\begin{array}{c}\text { Soil } \\
\text { profile } \\
\text { depth } \\
\text { (m) }\end{array}$ & $\mathrm{SiO}_{2}$ & $\mathrm{Al}_{2} \mathrm{O}_{3}$ & $\mathrm{Fe}_{2} \mathrm{O}_{3}$ & MnO & $\begin{array}{c}\mathrm{MgO} \\
\%\end{array}$ & $\mathrm{CaO}$ & $\mathrm{Na}_{2} \mathrm{O}$ & $\mathbf{K}_{2} \mathbf{O}$ & $\mathrm{TiO}_{2}$ & $\mathrm{P}_{2} \mathrm{O}_{5}$ & L.O.I & $\begin{array}{c}\mathrm{Zr} \\
\text { ppm }\end{array}$ & CDF \\
\hline SC4 & 0.44 & 70.8 & 16.5 & 2.3 & 0.03 & 1.12 & 0.56 & 2.6 & 4.4 & 0.40 & 0.12 & 0.75 & 148.0 & 0.19 \\
\hline SC5 & 0.60 & 66.7 & 17.0 & 5.1 & 0.06 & 1.7 & 0.28 & 2.2 & 4.6 & 0.83 & 0.11 & 1.0 & 284.9 & 0.04 \\
\hline SC6 & 0.55 & 68.0 & 16.8 & 3.9 & 0.07 & 1.2 & 0.27 & 1.9 & 5.3 & 0.69 & 0.11 & 1.4 & 314.2 & 0.13 \\
\hline SC7 & 0.97 & 69.8 & 16.5 & 2.6 & 0.07 & 1.1 & 0.46 & 2.9 & 4.4 & 0.48 & 0.11 & 1.1 & 181.3 & 0.26 \\
\hline SC8 & 0.47 & 62.2 & 18.7 & 5.7 & 0.11 & 3.1 & 0.51 & 1.6 & 4.7 & 1.03 & 0.15 & 1.7 & 294.0 & 0.20 \\
\hline SC9 & 0.57 & 69.1 & 17.1 & 2.8 & 0.05 & 1.3 & 0.45 & 2.9 & 4.2 & 0.48 & 0.11 & 1.2 & 166.6 & 0.19 \\
\hline SC10 & 0.51 & 69.9 & 16.6 & 2.7 & 0.03 & 1.1 & 0.61 & 3.3 & 4.0 & 0.46 & 0.15 & 1.1 & 160.6 & 0.19 \\
\hline
\end{tabular}

195

\section{Results and discussion}

\subsection{Model testing and results}

The model was tested using in-situ soil moisture observations, in order to check that the model represents well the soil profile's hydrological balance before modelling chemical weathering reactions and material fluxes. The model was adjusted for rainfall

200 interception by vegetation. Figure 3 shows the $\mathrm{R}^{2}$ values, with the best correlation determined by the daily precipitation reduced by a fixed value of $2 \mathrm{~mm}$ and interception evaporation fraction of 0 . Consequently, all further simulations were carried out using this combination. The results are shown in Fig. 4, which compares the daily values of simulated and measured soil moisture content across a period of 1 year and 1-month (from November-2016 to December-2017) at the SC4 location, at the hilltop of SFS. Soil moisture values, both observed and simulated, vary between approximately $0.05\left(\mathrm{~m}^{3} \mathrm{~m}^{-3}\right)$ and $0.30\left(\mathrm{~m}^{3} \mathrm{~m}\right.$

$205^{3}$ ). The calibrated coefficient of determination $\left(\mathrm{R}^{2}\right)$ and the Nash-Sutcliffe Efficiency (NSE) index indicate a good fit of SoilGen to the observations, with values of 0.85 and 0.78 , respectively. Overall, most values fall close to the 1:1 line, although there is 
https://doi.org/10.5194/soil-2021-78

Preprint. Discussion started: 17 August 2021

(c) Author(s) 2021. CC BY 4.0 License.

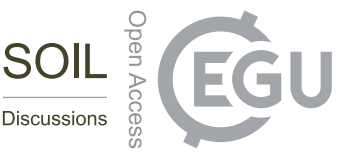

(c) (1)

a small overprediction of low soil moisture values and underprediction of high soil moisture values. However, given the complex soil conditions and variable Mediterranean climate, this prediction can be considered a valid representation of the actual soil hydrological dynamics.

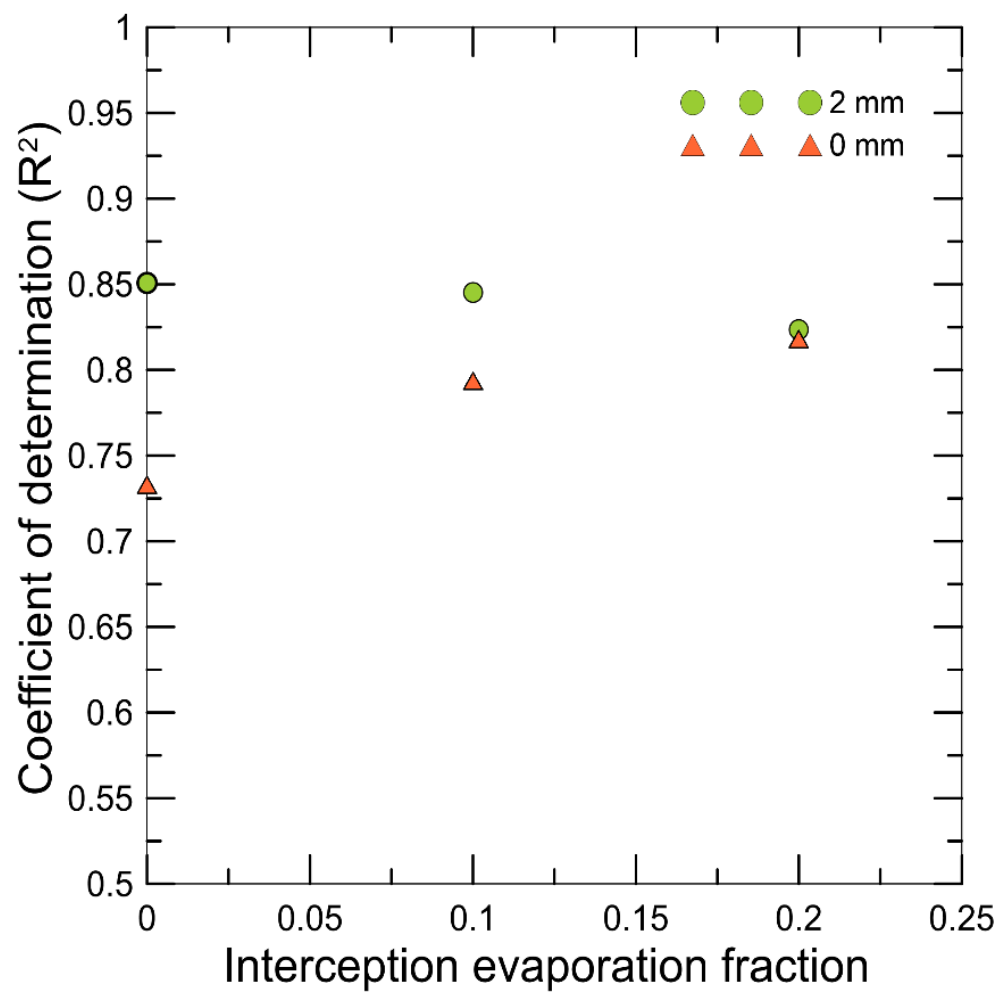

Figure 3: Coefficient of determination $\left(\mathbf{R}^{2}\right)$ calculated for different Interception evaporation fractions with the daily precipitation reduced by a fixed value of $2 \mathrm{~mm}$ and without reduction or $0 \mathrm{~mm}$. 


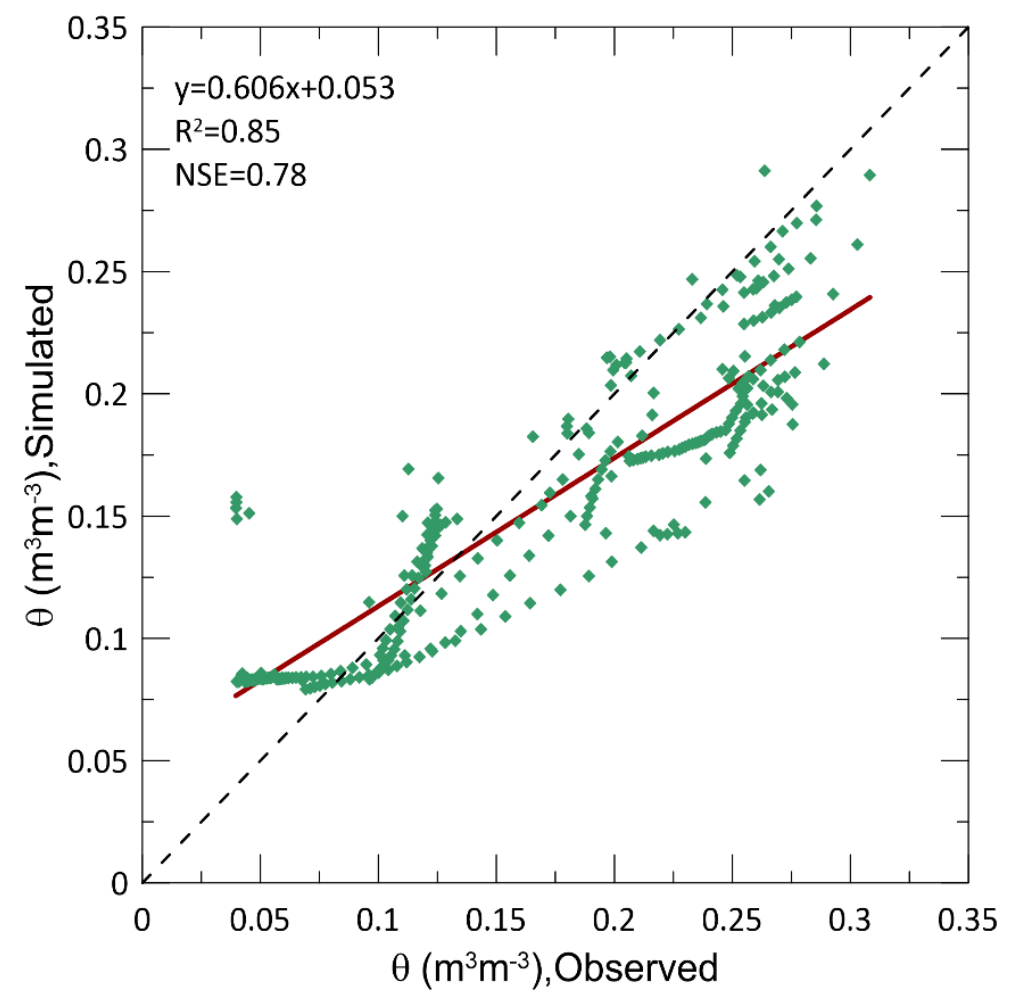

Figure 4: Relation between soil moisture content $(\theta)$ values simulated and measured at SC4 location. The coefficient of determination $\left(\mathbf{R}^{2}\right)$ and the Nash-Sutcliffe Efficiency (NSE) index are indicated.

A comparison between measured and modelled CDF values is shown in Fig. 5. Measured CDF values indicate an intermediate weathering of the soil profiles, with values ranging between 0.04 and 0.26 . The highest chemical weathering was measured in the profiles SC7 and SC8. Simulations with SoilGen generally represent the trend in the measured data well, although the data show an overall trend for $\mathrm{CDF}$ to be overpredicted (Fig. 5), as the average slope of the regression line $\left(\mathrm{CDF}_{\text {measured }}=0.630 \cdot \mathrm{CDF}_{\text {calculated }}+0.011\right)$ was significantly different from 1 . The $1: 1$ solid line (perfect model) and the 1:0.5 and 1:2 dashed lines (FAC2) were added to the scatter plot (Fig. 5) to assist the interpretation of the results. The results of the statistical metrics (Table 4) met the criteria suggested by Kumar et al. (1993): the performance of a model can be deemed as acceptable if FAC2 $\geq 0.80$, being the ideal value $1.0(100 \%)$, NMSE $\leq 0.5$, and $-0.5 \leq \mathrm{FB} \geq+0.5$, Taken this into account, the obtained FAC2, NMSE, and FB values are quite acceptable and equal to 0.86, 0.22 and -0.39 , respectively. According to the FAC2 value, $86 \%$ of simulated values were within a factor of two of the measured values. A negative value of FB indicates model overestimation whereas RMSE and NMSE do not account for over or underestimation but their ideal value is zero (Brancher et al., 2020). Note that the metric results shown are dimensionless because CDF is a non-dimensional quantity. The model, therefore, represents the measured trend in CDF values correctly, although there exists a positive bias. However, given the fact that the model is uncalibrated in terms of chemical reactions and with respect to the resulting soil properties, we consider this result to be satisfactory. Indeed, some degree of bias can be expected, in part since this 1-D model 
https://doi.org/10.5194/soil-2021-78

Preprint. Discussion started: 17 August 2021

(c) Author(s) 2021. CC BY 4.0 License.

(c) (1)

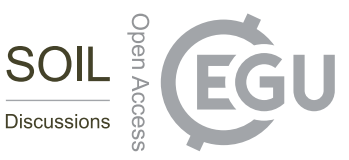

is not set up to handle possible lateral fluxes of water and chemical weathering products but also because of the large time scale of the modelled processes, a common problem in this type of soil formation studies (reference review paper by Opolot and Finke (2015)).

The low CDF in SC5 location, considering the minimum $\mathrm{Zr}$ value measured in the soil profile, indicates that the complete soil profile is highly weathered. This is associated with lower $\mathrm{SiO}_{2}$ and higher $\mathrm{MgO}$ values with respect to the other locations (Table 3) and could be related to mafic intrusions because of differences in bedrock mineral composition which result in higher rock weatherability. Oeser et al., (2018), in their study along a steep climate and vegetation gradient in the Chilean Coastal Cordillera, attributed a high degree of weathering ( $C D F \approx 0.4-0.5)$ in Santa Gracia sites to a more mafic composition of the bedrock. Further evidence corroborating the different rock composition at the SC5 site and its consideration as an outlier is 240 given by the surface topography, as shown in Fig. 6. It can be seen that a small knickpoint is present just upslope of SC5, which could indicate indeed a higher weatherability around SC5.

Based on the chemical composition alone (Table 3), also the SC8 location is characterized by low $\mathrm{SiO}_{2}$ and high $\mathrm{MgO}$ values, corresponding to mafic rocks. However, the simulated CDF at this location does not deviate as much from the measured values as in SC5. This location on the NFS shows denser vegetation than location SC5 on the SFS (Fig. 6), due to the higher water 245 availability on the NFS (García-Gamero et al., 2021). Oeser \& von Blanckenburg (2020) pointed out that the presence of denser vegetation might counteract a potential weathering increase in their study along the climate and vegetation gradient in the Chilean Coastal Cordillera. This could explain why SC8 is not an outlier, similar to SC5. While the underlying reasons for any deviations between modelled and measured CDF values are certainly complex, they will be explored below in more detail, in order to try to establish systematic relations between CDF and topographic and hydrological variables. 


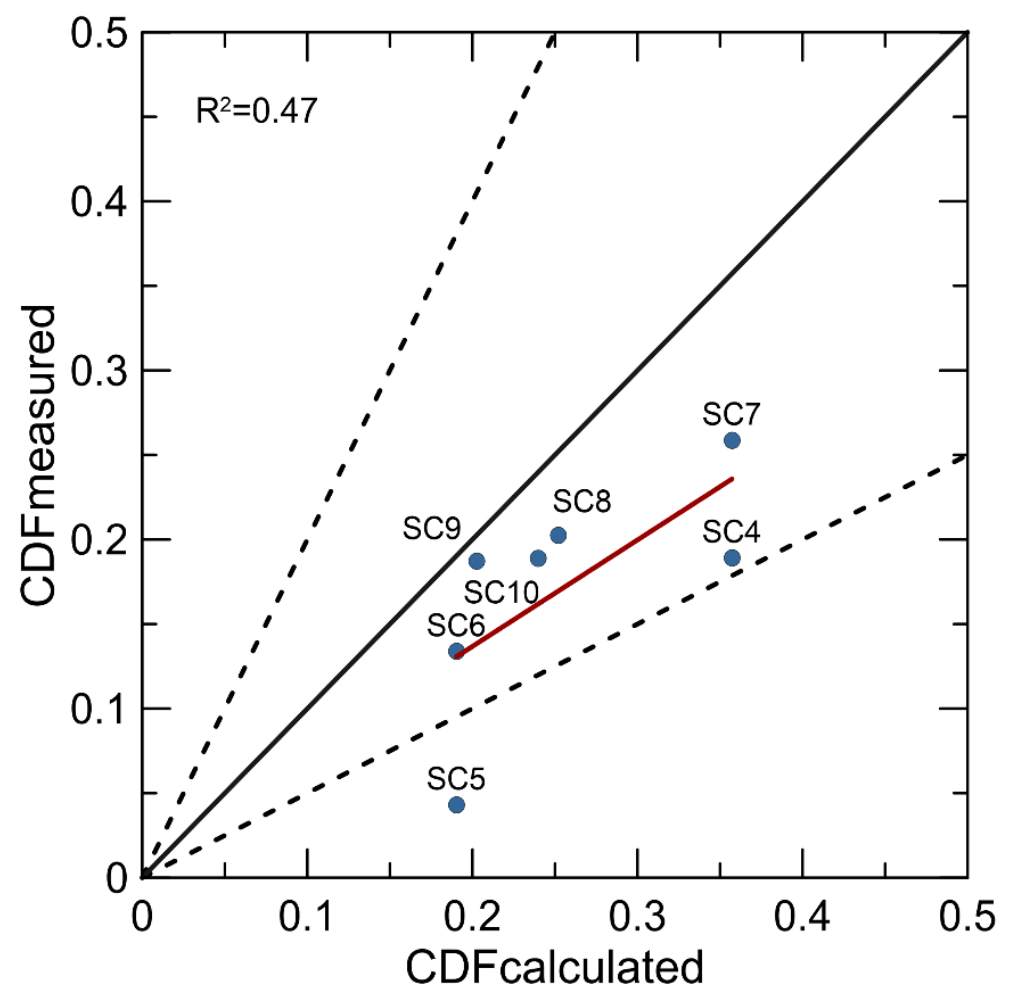

Figure 5: Relation between CDF values calculated based on simulations and measured based on field samples. The 1:1 line (solid) represents the perfect model and the 1:0.5 and 1:2 lines (dashed) embrace the data within a factor of two (FAC2). The coefficient of determination $\left(\mathbf{R}^{2}\right)$ is indicated.

Table 4. Statistical metrics of performance evaluation comparing measured and calculated CDF. n: number of observations, FAC2: Fraction of predictions within a factor of 2, FB: Fractional bias, RMSE: Root mean square error, NMSE: Normalized mean square error.

\begin{tabular}{ccccc}
\hline $\mathbf{n}$ & FAC2 & FB & RMSE & NMSE \\
\hline $\mathbf{7}$ & 0.86 & -0.39 & 0.099 & 0.22
\end{tabular}

\subsection{Topographic and hydrological effect in CDF}

The SoilGen model was applied to test the hypothesis that CDF values could be explained by landscape position and simulated by a simple one-dimensional model. Any deviations can then be analyzed to identify model shortcomings and future needs for model improvement.

To analyze the effect of topographic position along the catena, measured and simulated CDF values together with the conceptual model of the subsurface of the Critical Zone (the zone of the Earth surface that extends from the top of the canopy to the bottom of the groundwater) in the study site are shown in Fig. 6. As mentioned in Fig. 5, simulated and measured CDF values generally have the same trend, except for SC5. Higher simulated values were observed on the hilltop, SC4, and the 
https://doi.org/10.5194/soil-2021-78

Preprint. Discussion started: 17 August 2021

(c) Author(s) 2021. CC BY 4.0 License.

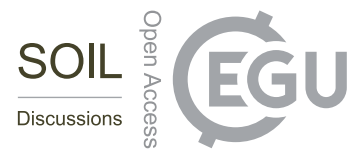

valley bottom, SC7, followed by location SC8 in the middle slope of the NFS (Fig. 6). These locations were among those with the lowest local slope gradient, except for SC8.

270 The position along the toposequence alone did not explain well the spatial variation of the CDF, so it has to be concluded that its variation is due to other factors that are considered in the model and will be analyzed.
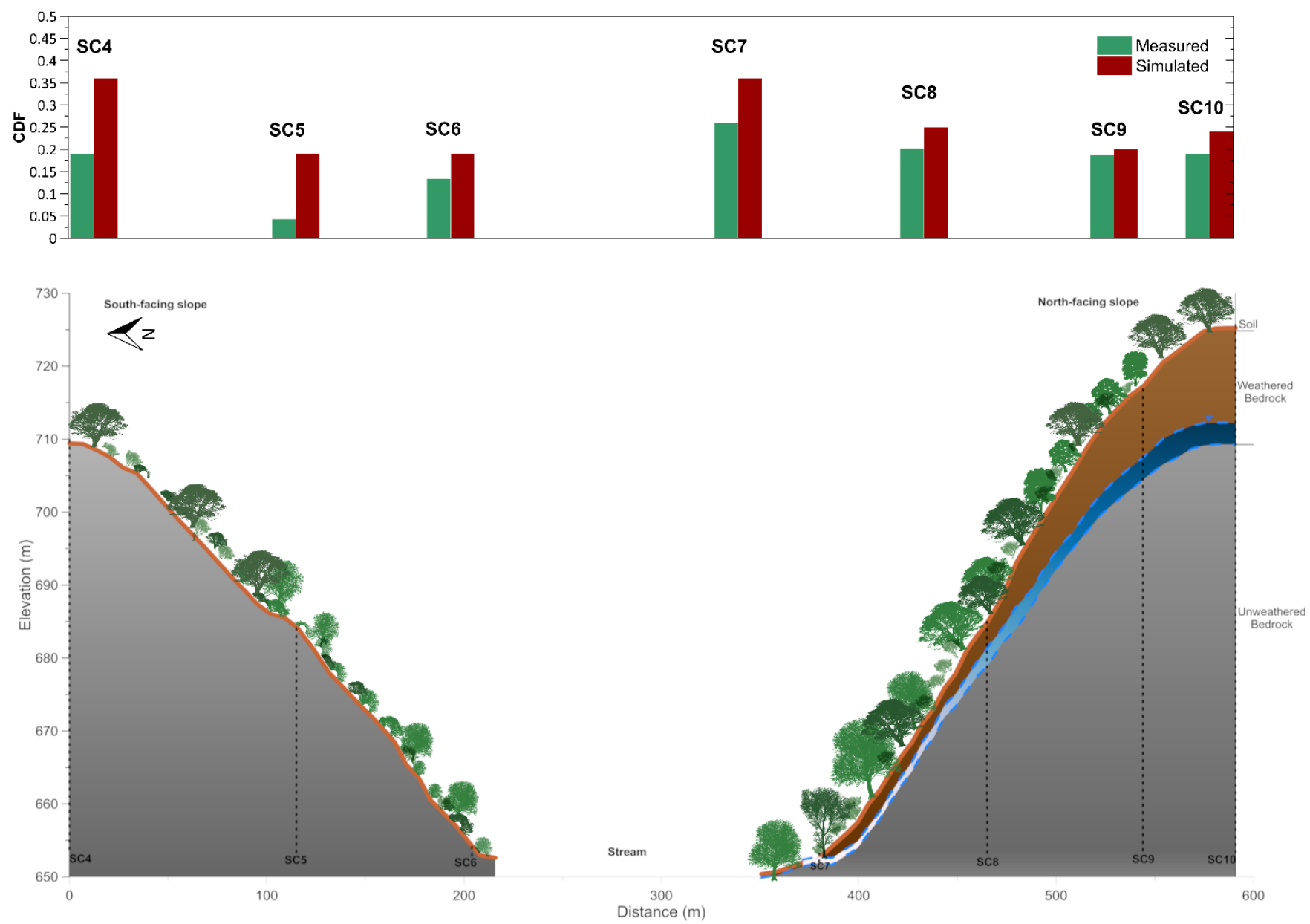

Figure 6: Variation of measured (green bars) and simulated (red bars) chemical depletion fraction (CDF) (top panel) along the studied north-south catena, including a schematic representation (bottom panel) of the vegetation, surface topography, soil, weathered bedrock, and unweathered bedrock. On the NFS we also distinguish a seasonal groundwater table (blue).

The relation of CDF values with different external factors was considered in Fig. 7. The variation of CDF along the toposequence was related to local slope gradient (Fig. 7a) and because the role of soil water hydrology on chemical weathering with hydrological parameters, i.e., infiltration ( $\left.\mathrm{I} \mathrm{m}^{3} \mathrm{yr}^{-1}\right)$ (Fig. $7 \mathrm{~b}$ ), average moisture content $\left(\theta, \mathrm{m}^{3} \mathrm{~m}^{-3}\right)$ (Fig. $7 \mathrm{c}$ ), and water residence time (RT, yr) (Fig. 7d). The hydrological parameters were derived from the simulations. 
https://doi.org/10.5194/soil-2021-78

Preprint. Discussion started: 17 August 2021

(c) Author(s) 2021. CC BY 4.0 License.

(c) (i)

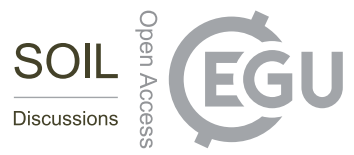

The results indicated an absence of correlation with the current slope (Fig 7a), although the highest CDF values were found for two soil profiles with a low slope gradient (SC4 and SC7), this was not the case for SC10. On the other hand, the data indicates a positive relationship with average moisture content and infiltration. This implies that higher infiltration leads to higher chemical weathering. A negative relation was observed with residence time, implying that a faster throughflow of reactive water from rainfall speeds up the weathering process. The absence of statistically significant relations for slope and these hydrological parameters indicates the complexity of the modeled processes. One reason for this is the long-time scale of modelling, and the current topography might not have been constant during the full period of weathering. This problem is also recurrent in simulations of historical soil erosion (Peeters et al., 2006).
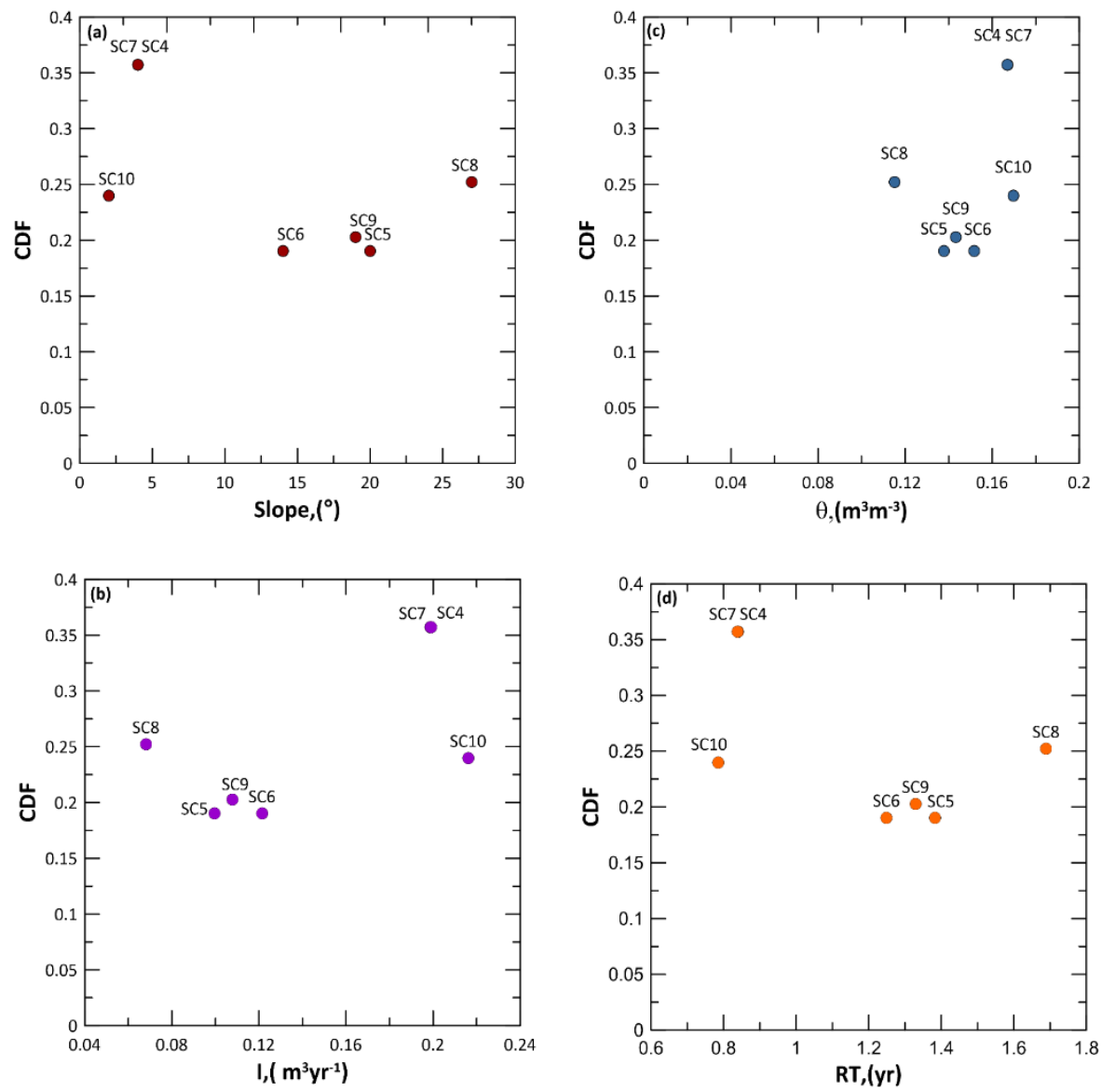

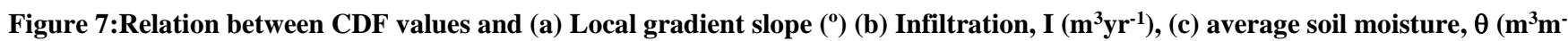
3) and (d) Water Residence Time, RT (yr).

The good relation between chemical weathering and hydrological variables corroborates previous studies that concluded the hydrological control on chemical weathering to be dominant (Maher, 2010; Maher and Chamberlain, 2014). These authors indicate that natural systems can generally be considered to be transport-controlled, where the reaction rate of chemical 
https://doi.org/10.5194/soil-2021-78

Preprint. Discussion started: 17 August 2021

(c) Author(s) 2021. CC BY 4.0 License.

(c) (i)

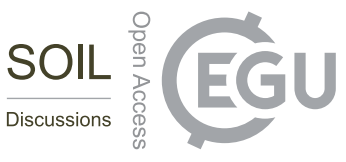

weathering processes depends mostly on the departure from the equilibrium. This departure is controlled by the water flow rate through the profile and how fast or slow weathered products are exported from the soil profile. In other words, in transportcontrolled weathering systems, flow rates and solubility by definition will be the dominant control on mass removal. As natural systems are difficult to characterize fully, not much field data has been collected corroborating this so far. Some studies, like Schoonejans et al. (2016) found a positive relation between chemical weathering and rainfall along a climatic gradient in southern Spain. However, the results of this study, both measured and modelled CDF values, are among the first to find differences in chemical weathering in different landscape positions along a catena. In this study area, rainfall is homogeneous, but the differences in infiltration can be purely attributed to differences in exposition and landscape position. Further studies will be needed, not only at the landscape or regional scale but also at a shorter spatial scale, such as this catena-scale study to elucidate these hydrological effects in more detail. Some authors have pointed to important feedbacks with plants, that definitely can have a significant impact on soil hydrology and perhaps also a direct influence on chemical weathering processes (Cipolla et al., 2021; Porada et al., 2016).

The results of this study are in contrast with observations by Molina et al. (2019) on 10 toposequences in a High Andean catchment. They observed only a marginally significant topographic control on chemical weathering extent, while our data varies considerably between landscape positions. Rather than topography, Molina et al. (2019) concluded that vegetation exerted an important control, as they found highly significant differences in chemical weathering extent between vegetation communities. In their study, however, they compared very different vegetation types, ranging from forest to grass and cushionforming plants. In our study, vegetation is more similar between SFS and NFS, although vegetation is denser on the latter. Although counterintuitively, in previous work in the study site to characterize the hydrological dynamics using soil moisture

315 sensors and piezometers, García-Gamero et al. (2021) observed very similar surface hydrological dynamics between the NFS and SFS. In fact, daily soil moisture storage change differences between both opposing slopes did not suggest more interception on the NFS (García-Gamero et al., 2021), despite the denser vegetation. The denser vegetation cover on the NFS only caused it to dry out somewhat earlier during the year compared to the SFS. However, subsurface water dynamics were found to be significantly different, with a deeper weathered bedrock on the NFS (Fig. 6) that allows seasonal water storage and a significant lateral water flow.

The model SoilGen could be further improved by taking into account lateral fluxes of water and sediment. The one-dimensional SoilGen model does not consider lateral fluxes by definition. These lateral water fluxes on the NFS can explain the higher measured $\mathrm{CDF}$ values in SC9, SC8 and particularly in SC7. The points located along this north-facing hillslope all receive an additional lateral water influx, which is greatest for SC7 at the bottom of the hillslope. This lateral water flux can accelerate the chemical weathering and is not considered in the one-dimensional model. At present, as far as the authors know, no soil profile formation model exists that has this capability. On the other hand, on the SFS soils are shallower and this lateral connectivity does not exist. The other profile on the SFS, SC6 however does behave as expected and is characterized by the lowest CDF values, except for SC5 above mentioned, both measured and simulated. To take into account these lateral fluxes 
https://doi.org/10.5194/soil-2021-78

Preprint. Discussion started: 17 August 2021

(c) Author(s) 2021. CC BY 4.0 License.

(c) (i)

goes beyond the objectives of this paper that aims to model chemical weathering with a simple model, but future modelling 330 efforts should be pointed in this direction.

\subsection{Climatic effect on chemical weathering: Sensitivity Analysis}

After analyzing the variability in soil formation along the north-south oriented catena, the effect of a simulated precipitation gradient (200-1200 mm) on the CDF was studied, at one fixed, representative location, SC10 (Fig. 8).

The lowest CDF values throughout the profile correspond to the lowest precipitation value of $200 \mathrm{~mm}$, as expected. For this

precipitation value, there is very little difference of CDF with depth. Increasing precipitation to $400 \mathrm{~mm}$ leads to a sudden increase in the weathering of the top $40 \mathrm{~cm}$ of the profile, with a marked depth gradient and similar CDF values in depth compared to the $200 \mathrm{~mm}$ case. A precipitation increase to $600 \mathrm{~mm}$ does not change the CDF-depth pattern much, although the weathering front lowers. For $\mathrm{P}=800 \mathrm{~mm}$ the weathering and $\mathrm{CDF}$ values in depth increase markedly. However, for $\mathrm{P}>800$ $\mathrm{mm}$, the CDF values are again lower and are all characterized by a uniform depth distribution (Fig. 8).

340 These simulated depth patterns are comparable to those measured in the eastern part of the Betic Cordillera located in Southeast Spain by Schoonejans et al. (2016).

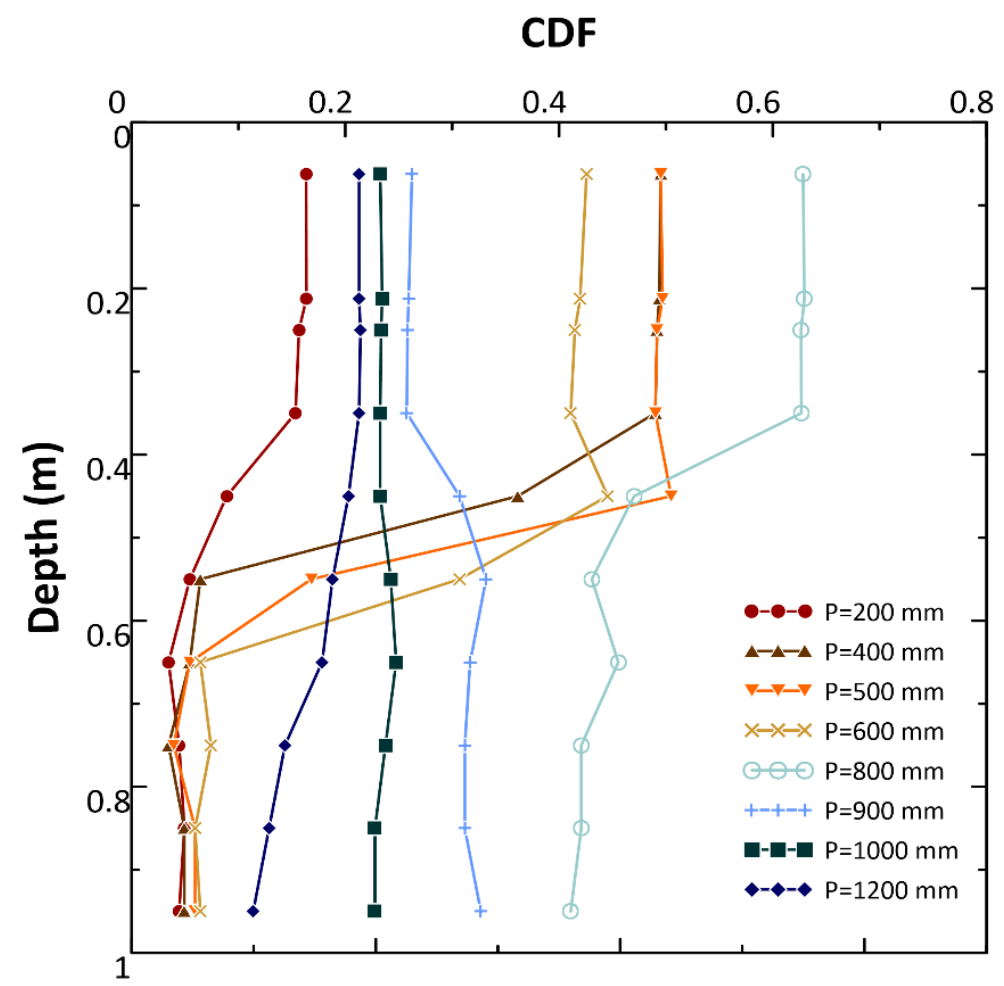

Figure 8: Weathering intensity (expressed by the chemical depletion fraction, CDF) of a soil profile under different annual rainfall (P). Profiles are simulated in the SC10 location, at the hilltop.

345 Figure 9 then shows the total CDF, averaged over the entire soil depth, i.e., $1 \mathrm{~m}$ of the soil profile. The results from this study, represented by the blue dots, showed an increased weathering up to $800 \mathrm{~mm}$, but after this critical value, the profiles were less 
https://doi.org/10.5194/soil-2021-78

Preprint. Discussion started: 17 August 2021

(c) Author(s) 2021. CC BY 4.0 License.

(c) (i)

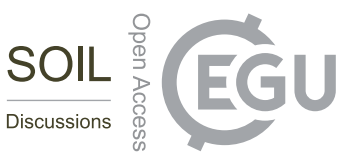

weathered. Moreover, in Fig. 9 CDFs of this study are compared to a global data compilation of granitic soil-mantled hillslopes (Schaller and Ehlers, 2021). Also, this global dataset seems to indicate that high weathering rates measured as CDF are not obtained with the highest precipitation values, but rather with intermediate precipitation. With precipitations less than $800 \mathrm{~mm}$, a substantial part of the year will have a precipitation deficit. This means that leaching is of less importance and concentrations of cations released by weathering in the soil solution will be high. One theory often applied to quantify weathering is the transition state theory (TST). In the quantification of weathering fluxes by TST, the dissolution rate of a mineral is the product of the rate parameter (which is often a function of $\mathrm{pH}$ ) and the degree of saturation of the soil solution with respect to the dissolving mineral. Drier climates often result in a higher $\mathrm{pH}$ and a higher degree of saturation, which both (and certainly in combination) lead to lower weathering rates for most minerals. The decreasing weathering rates imply decreasing CDF values with lower precipitation. On the other hand, an explanation for the right part of the curve, where CDF values decrease with increasing precipitation is less straightforward. Possibly, with increasing precipitation surplus, travel times of water may be shorter and then contact time with the minerals is shorter, which slows down the dissolution rate. Additionally, vegetation will be lusher, and then the nutrient pump may prevent leaching of some elements. Both will decrease the CDF.

360 This threshold or maximum weathering correspondent to intermediate precipitation is coincident with the maximum generalization of Albrecht's curve, which is shown in Fig. 9 by the grey shaded area. Huston (2012) pointed out the link between climate and soil formation and properties that scientists such as William Albrecht generalized 80 years ago. Albrecht's curve (e.g. Albrecht, 1957) is a rule that illustrated the effect of precipitation on soil-forming processes and soil properties (Huston, 2012). In this diagram, which presents a maximum in the center, the effect of a precipitation gradient on the rates of physical, chemical, and biological processes that affect pedogenesis and important soil properties are shown. Different later works that have studied soil properties and weathering along a marked precipitation gradient (e.g. Chadwick et al., 2003) confirmed Albrecht's curve. Similarly, Dixon et al. (2016) in their study for chemical weathering in postglacial soils of New Zealand found an important pedogenic threshold coincident at mean annual precipitation of $\sim 800 \mathrm{~mm}$-yr-1, very similar to the threshold value that was identified in this sensitivity analysis. Oeser \& von Blanckenburg (2020) on the other hand, in their study in the EarthShape Critical Zone located along the Chilean Coastal Cordillera, found no correlation between the degree of weathering and mean annual precipitation. Therefore, they pointed out that a competitive effect seems to offset the expected increase in the rate of weathering with precipitation. Huston (2012) even related this concept of the Albrecht curve to ecosystem trends. He analyzed global variations in soil properties, Net Primary Productivity and biodiversity as a function of precipitation. He found similar, unimodal curves with maximum values for soil properties such as total exchangeable bases and found that the maximum corresponded to the point where precipitation is equal to the evapotranspiration rate. Given the importance of soil properties and chemical weathering of soil profiles for ecosystem response, these results can be far-fetching consequences and should be explored further with more simulations and profile data. 
https://doi.org/10.5194/soil-2021-78

Preprint. Discussion started: 17 August 2021

(c) Author(s) 2021. CC BY 4.0 License.

(c) (i)

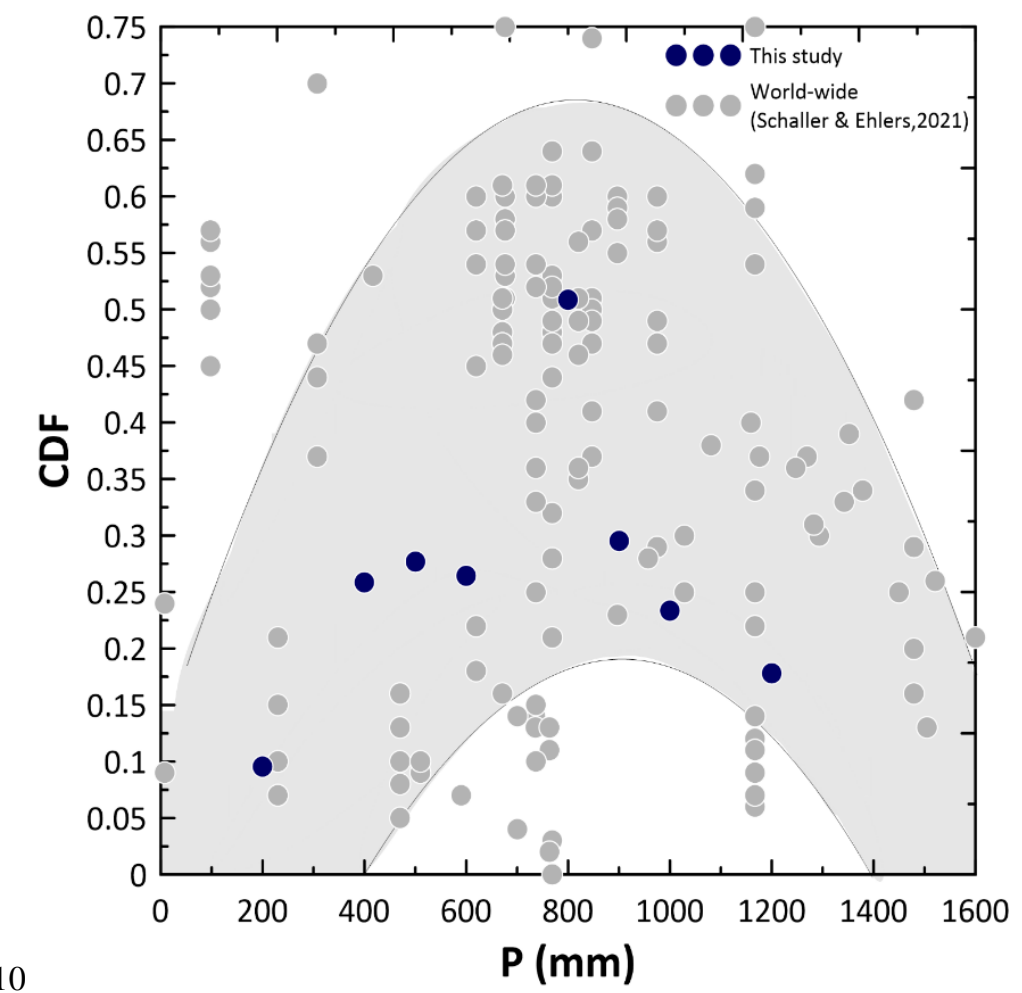

Figure 9: Chemical weathering (CDF) versus annual precipitation. The expected trend is indicated by the shaded area and follows a parabolic pattern with maximum chemical weathering for intermediate precipitation. Observations from this study are depthaveraged (blue dots). Observations from other study sites situated in granitic soil-mantled hillslopes (grey dots) are from a review by Schaller \& Ehlers (2021).

\section{Conclusions}

The effect of topographic position and hydrology on chemical weathering was analyzed in soils formed on granites under a

Mediterranean climate. Chemical depletion fraction was measured and modelled in seven locations, selected along a northsouth oriented catena in southern Spain. The model SoilGen was used to simulate pedogenesis and the measured chemical weathering status over a 20000-year period.

Despite the complexity of the catena and the hydrological conditions, a good correspondence was obtained between modelled and measured CDF. The variability of CDF values was explained better by hydrological variables than by topography. No clear relation to the catena position was found. No relation with slope gradient was observed. However, the CDF data did indicate a positive relation to the hydrological variables of soil moisture and infiltration, and a negative relation to water residence time. In addition, differences between measured and simulated CDF values could be attributed to lateral water fluxes that are not considered in the model.

The model sensitivity was evaluated with different precipitation regimes. The results showed a marked depth gradient for rainfall under $800 \mathrm{~mm}$ for the $\mathrm{CDF}$, but it showed a uniform depth distribution for precipitation above $800 \mathrm{~mm}$. For the profile average chemical weathering, maximum values were observed for intermediate precipitation values, around $800 \mathrm{~mm}$. 
https://doi.org/10.5194/soil-2021-78

Preprint. Discussion started: 17 August 2021

(c) Author(s) 2021. CC BY 4.0 License.

(c) (i)

\section{Data availability}

Data are available upon request to the authors.

\section{Author contribution}

400 TV and VGG conceived and designed the study with substantial input from PF and AP. ARS and TV performed the sampling. The data curation and formal analysis, methodology, and visualization for the paper were performed by VGG, with substantial input from PF and TV. VGG and PF performed the simulations. VGG wrote the first draft. All the authors (VGG, TV, AP, ARS, and PK) contributed to generating and reviewing the subsequent versions of the paper.

\section{Competing interests}

405 Peter Finke is topical editor of SOIL journal. All other authors declare that they have no conflict of interest.

\section{Acknowledgments}

This work is supported by the project "Estableciendo un Observatorio de la Zona Crítica para la Hidropedología y Agricultura Sostenible en el Mediterráneo" (AGL2015-65036-C3-2-R) funded by Programa Estatal de Investigación, Desarrollo e Innovación orientada a los retos de la sociedad 81/150 para el cuatrienio 2016-2020 (MINECO/FEDER, UE). Vanesa GarcíaGamero was awarded with a FPU fellowship (FPU15/05279) from the Spanish Ministry of Education, Culture and Sport. This paper was the result of a research stay of Vanesa García-Gamero at Ghent University, funded by the fellowship "Becas Movilidad Internacional" (2017-2018) from Universidad de Córdoba.

Vanwalleghem thanks funding to the Department of Agronomy by the Spanish Ministry of Science and Innovation, the Spanish State Research Agency, through the Severo Ochoa and María de Maeztu Program for Centers and Units of Excellence in R\&D

(Ref. CEX2019-000968-M).

\section{References}

Albrecht, W. A.: Soil Fertility and Biotic Geography, Geogr. Rev., 47(1), 86, doi:10.2307/212191, 1957.

Borden, R. W., Baillie, I. C. and Hallett, S. H.: The East African contribution to the formalisation of the soil catena concept, Catena, 185(November 2019), doi:10.1016/j.catena.2019.104291, 2020.

Brancher, M., Hieden, A., Baumann-Stanzer, K., Schauberger, G. and Piringer, M.: Performance evaluation of approaches to predict sub-hourly peak odour concentrations, Atmos. Environ. X, 7(April), 100076, doi:10.1016/j.aeaoa.2020.100076, 2020. Brantley, S. L., Eissenstat, D. M., Marshall, J. A., Godsey, S. E., Balogh-Brunstad, Z., Karwan, D. L., Papuga, S. A., Roering, J., Dawson, T. E., Evaristo, J., Chadwick, O., McDonnell, J. J. and Weathers, K. C.: Reviews and syntheses: On the roles trees play in building and plumbing the critical zone, Biogeosciences, 14(22), 5115-5142, doi:10.5194/bg-14-5115-2017, 2017. Braun, J., Mercier, J., Guillocheau, F. and Robin, C.: A simple model for regolith formation by chemical weathering, J. Geophys. Res. Earth Surf., 2140-2171, doi:10.1002/2016JF003914.Received, 2016.

Calabrese, S. and Porporato, A.: Wetness controls on global chemical weathering, Environ. Res. Commun., 2(8), 085005, doi:10.1088/2515-7620/abad7b, 2020.

Carpintero, E., Andreu, A., Gómez-Giráldez, P. J., Blázquez, Á. and González-Dugo, M. P.: Remote-Sensing-Based Water 430 Balance for Monitoring of Evapotranspiration and Water Stress of a Mediterranean Oak - Grass Savanna, Water, 2020. 
https://doi.org/10.5194/soil-2021-78

Preprint. Discussion started: 17 August 2021

(c) Author(s) 2021. CC BY 4.0 License.

\section{(c) (1)}

Carracedo, M., Paquette, J. L., Alonso Olazabal, A., Santos Zalduegui, J. F., de García de Madinabeitia, S., Tiepolo, M. and Gil Ibarguchi, J. I.: U-Pb dating of granodiorite and granite units of the Los Pedroches batholith. Implications for geodynamic models of the southern Central Iberian Zone (Iberian Massif), Int. J. Earth Sci., 98(7), 1609-1624, doi:10.1007/s00531-0080317-0, 2009.

435 Chadwick, O. A., Gavenda, R. T., Kelly, E. F., Ziegler, K., Olson, C. G., Crawford Elliott, W. and Hendricks, D. M.: The impact of climate on the biogeochemical functioning of volcanic soils, Chem. Geol., 202(3-4), 195-223, doi:10.1016/j.chemgeo.2002.09.001, 2003.

Chadwick, O. A., Roering, J. J., Heimsath, A. M., Levick, S. R., Asner, G. P. and Khomo, L.: Shaping post-orogenic landscapes by climate and chemical weathering, Geology, 41(11), 1171-1174, doi:10.1130/G34721.1, 2013.

440 Cipolla, G., Calabrese, S., Valerio, L. and Porporato, A.: Modeling rock-dissolution reactions coupled to plant, soil moisture , and carbon dynamics, Adv. Water Resour., (December 2020), 103934, doi:10.1016/j.advwatres.2021.103934, 2021.

Cohen, S., Willgoose, G. and Hancock, G.: The mARM3D spatially distributed soil evolution model: Three-dimensional model framework and analysis of hillslope and landform responses, J. Geophys. Res. Earth Surf., 115(4), 1-16, doi:10.1029/2009JF001536, 2010.

445 Dahlgren, R. A., Boettinger, J. L., Huntington, G. L. and Amundson, R. G.: Soil development along an elevational transect in the western Sierra Nevada, California, Geoderma, 78(3-4), 207-236, doi:10.1016/S0016-7061(97)00034-7, 1997.

Davis, B. A. S., Brewer, S., Stevenson, A. C., Guiot, J., Allen, J., Almqvist-Jacobson, H., Ammann, B., Andreev, A. A., Argant, J., Atanassova, J., Balwierz, Z., Barnosky, C. D., Bartley, D. D., De Beaulieu, J. L., Beckett, S. C., Behre, K. E., Bennett, K. D., Berglund, B. E. B., Beug, H. J., Bezusko, L., Binka, K., Birks, H. H., Birks, H. J. B., Björck, S., Bliakhartchouk, T., Bogdel,

450 I., Bonatti, E., Bottema, S., Bozilova, E. D. B., Bradshaw, R., Brown, A. P., Brugiapaglia, E., Carrion, J., Chernavskaya, M., Clerc, J., Clet, M., Coûteaux, M., Craig, A. J., Cserny, T., Cwynar, L. C., Dambach, K., De Valk, E. J., Digerfeldt, G., Diot, M. F., Eastwood, W., Elina, G., Filimonova, L., Filipovitch, L., Gaillard-Lemdhal, M. J., Gauthier, A., Göransson, H., Guenet, P., Gunova, V., Hall, V. A. H., Harmata, K., Hicks, S., Huckerby, E., Huntley, B., Huttunen, A., Hyvärinen, H., Ilves, E., Jacobson, G. L., Jahns, S., Jankovská, V., Jóhansen, J., Kabailiene, M., Kelly, M. G., Khomutova, V. I., Königsson, L. K.,

Kremenetski, C., Kremenetskii, K. V., Krisai, I., Krisai, R., Kvavadze, E., Lamb, H., Lazarova, M. A., Litt, T., Lotter, A. F., Lowe, J. J., Magyari, E., Makohonienko, M., Mamakowa, K., Mangerud, J., Mariscal, B., Markgraf, V., McKeever, Mitchell, F. J. G., Munuera, M., Nicol-Pichard, S., Noryskiewicz, B., Odgaard, B. V., Panova, N. K., Pantaleon-Cano, J., Paus, A. A., Pavel, T., Peglar, S. M., Penalba, M. C., Pennington, W., Perez-Obiol, R., et al.: The temperature of Europe during the Holocene reconstructed from pollen data, Quat. Sci. Rev., 22(15-17), 1701-1716, doi:10.1016/S0277-3791(03)00173-2, 2003.

De Vries, W. and Posch, M.: Derivation of cation exchange constants for sand loess, clay and peat soils on the basis of field measurements in the Netherlands, Alterra Green World research, Wageningen., 2003.

Dixon, J. ., Heimsath, A. M. and Amundson, R.: The critical role of climate and saprolite weathering in landscape evolution, Earth Surf. Process. Landforms, 34, 1507-1521, doi:10.1002/esp.1836, 2009.

Dixon, J. L., Chadwick, O. A. and Vitousek, P. M.: Climate-driven thresholds for chemical weathering in postglacial soils of 
https://doi.org/10.5194/soil-2021-78

Preprint. Discussion started: 17 August 2021

(c) Author(s) 2021. CC BY 4.0 License.

(c) (i)

465 New Zealand, J. Geophys. Res. Earth Surf., 1619-1634, doi:10.1002/2016JF003864, 2016.

Duarte, I. M. R., Gomes, C. S. F. and Pinho, A. B.: Chemical Weathering, in Encyclopedia of Engineering Geology.Encyclopedia of Earth Sciences Series., edited by P. T. Bobrowsky and B. Marker, Springer,Cham., 2018.

Ferrier, K. L. and Perron, J. T.: The importance of hillslope scale in responses of chemical erosion rate to changes in tectonics and climate, Am. Geophys. Union, doi:10.1029/2020JF005562, 2020.

470 Finke, P. A.: Modeling the genesis of luvisols as a function of topographic position in loess parent material, Quat. Int., 265, 3-17, doi:10.1016/j.quaint.2011.10.016, 2012.

Finke, P. A. and Hutson, J. L.: Modelling soil genesis in calcareous loess, Geoderma, 145, 462-479, doi:10.1016/j.geoderma.2008.01.017, 2008.

Finke, P. A., Vanwalleghem, T., Opolot, E., Poesen, J. and Deckers, J.: Estimating the effect of tree uprooting on variation of soil horizon depth by confronting pedogenetic simulations to measurements in a Belgian loess area, J. Geophys. Res. Earth Surf., 118, 2124-2139, doi:10.1002/jgrf.20153, 2013.

Gabet, E. J. and Mudd, S. M.: A theoretical model coupling chemical weathering rates with denudation rates, Geology, 37(2), 151-154, doi:10.1130/G25270A.1, 2009.

García-Gamero, V., Peña, A., Laguna, A. M., Giráldez, J. V. and Vanwalleghem, T.: Factors controlling the asymmetry of soil

480 moisture and vegetation dynamics in a hilly mediterranean catchment, J. Hydrol., 598(October 2020), 126207, doi:10.1016/j.jhydrol.2021.126207, 2021.

Gobat, J.-M., Aragno, M. and Matthey, W.: Le Sol Vivant, Les Presses polytechniques et universitaires romandes, Lausanne., 1998.

Hargreaves, G. H. and Samani, Z. A.: Reference Crop Evapotranspiration from Temperature, Pap. - Am. Soc. Agric. Eng., 96$48599,1985$.

Huston, M. A.: Precipitation, soils, NPP, and biodiversity: Resurrection of Albrecht's curve, Ecol. Monogr., 82(3), 277-296, doi:10.1890/11-1927.1, 2012.

Jenny, H.: Factors of soil formation: A System of Quantitative Pedology, McGraw-Hill Book Company Inc., New york., 1941. Kumar, A., Luo, J. and Bennett, G. F.: Statistical evaluation of Lower Flammability Distance (LFD) using four hazardous 490 release models, Process Saf. Prog., 12(1), 1-11, doi:10.1002/prs.680120103, 1993.

Lachassagne, P. and Wyns, R.: Review article The fracture permeability of Hard Rock Aquifers is due neither to tectonics , nor to unloading, but to weathering processes, Terra Nov., 145-161, doi:10.1111/j.1365-3121.2011.00998.x, 2011.

Langston, A. L., Tucker, G. E., Anderson, R. S. and Anderson, S. P.: Exploring links between vadose zone hydrology and chemical weathering in the Boulder Creek critical zone observatory, Appl. Geochemistry, 495 doi:10.1016/j.apgeochem.2011.03.033, 2011.

Larsen, I. J., Almond, P. C., Eger, A. and Stone, J. O.: Reports 11., , 343(February), 637-641, 2014.

Lebedeva, M. I. and Brantley, S. L.: Lebedeva Marina (Orcid ID: 0000-0003-4987-4182) Relating the depth of the water table to depth of weathering, Earth Surf. Process. Landforms, 0-3, doi:10.1002/esp.4873, 2020. 
https://doi.org/10.5194/soil-2021-78

Preprint. Discussion started: 17 August 2021

(c) Author(s) 2021. CC BY 4.0 License.

(c) (i)

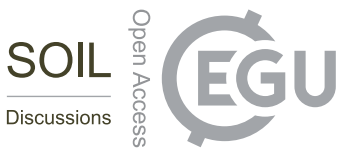

Maher, K.: The dependence of chemical weathering rates on fl uid residence time, Earth Planet. Sci. Lett., 294(1-2), 101-110,

doi:10.1016/j.eps1.2010.03.010, 2010.

Maher, K.: The role of fluid residence time and topographic scales in determining chemical fluxes from landscapes, Earth Planet. Sci. Lett., 312(1-2), 48-58, doi:10.1016/j.eps1.2011.09.040, 2011.

Maher, K. and Chamberlain, C. P.: Hydrologic Regulation of Chemical, Science (80-. )., 1502, doi:10.1126/science.1250770, 2014.

Milne, G.: Some suggested units of classification and mapping particularly for East African soils, Soil Res. - Bodenkundliche Forschung, Suppl. to Proc. Int. Union Soil Sci. IV, 183-198, 1935.

Minasny, B. and McBratney, A. B.: A rudimentary mechanistic model for soil formation and landscape development II. A two-dimensional model incorporating chemical weathering, Geoderma, 103(1-2), 161-179, doi:10.1016/S00167061(01)00075-1, 2001.

Molina, A., Vanacker, V., Corre, M. D. and Veldkamp, E.: Patterns in Soil Chemical Weathering Related to Topographic Gradients and Vegetation Structure in a High Andean Tropical Ecosystem Journal of Geophysical Research : Earth Surface, JGR Earth Surf., 2019.

Mudd, S. M. and Furbish, D. J.: Using chemical tracers in hillslope soils to estimate the importance of chemical denudation under conditions of downslope sediment transport, J. Geophys. Res. Earth Surf., 111(2), doi:10.1029/2005JF000343, 2006.

515 Oeser, R. A. and Von Blanckenburg, F.: Do degree and rate of silicate weathering depend on plant productivity?, Biogeosciences, 17(19), 4883-4917, doi:10.5194/bg-17-4883-2020, 2020.

Oeser, R. A., Stroncik, N., Moskwa, L. M., Bernhard, N., Schaller, M., Canessa, R., van den Brink, L., Köster, M., Brucker, E., Stock, S., Fuentes, J. P., Godoy, R., Matus, F. J., Oses Pedraza, R., Osses McIntyre, P., Paulino, L., Seguel, O., Bader, M. Y., Boy, J., Dippold, M. A., Ehlers, T. A., Kühn, P., Kuzyakov, Y., Leinweber, P., Scholten, T., Spielvogel, S., Spohn, M., Übernickel, K., Tielbörger, K., Wagner, D. and von Blanckenburg, F.: Chemistry and microbiology of the Critical Zone along a steep climate and vegetation gradient in the Chilean Coastal Cordillera, Catena, 170(June), 183-203, doi:10.1016/j.catena.2018.06.002, 2018.

Olea, L. and San Miguel-Ayanz, A.: The Spanish dehesa, a traditional Mediterranean silvopastoral system, in 21st General meeting of the European Grassland Federation, pp. 1-15., 2006.

525 Opolot, E. and Finke, P. A.: Evaluating sensitivity of silicate mineral dissolution rates to physical weathering using a soil evolution model (SoilGen2.25), Biogeosciences, 12(22), 6791-6808, doi:10.5194/bg-12-6791-2015, 2015.

Opolot, E., Yu, Y. Y. and Finke, P. A.: Modeling soil genesis at pedon and landscape scales: Achievements and problems, Quat. Int., 376, 34-46, doi:10.1016/j.quaint.2014.02.017, 2015.

Peel, M. C., Finlayson, B. L. and McMahon, T. A.: Updated world map of the Köppen-Geiger climate classification, Hydrol. 530 Earth Syst. Sci., 11, 1633-1644, 2007.

Peeters, I., Rommens, T., Verstraeten, G., Govers, G., Van Rompaey, A., Poesen, J. and Van Oost, K.: Reconstructing ancient topography through erosion modelling, Geomorphology, 78(3-4), 250-264, doi:10.1016/j.geomorph.2006.01.033, 2006. 
https://doi.org/10.5194/soil-2021-78

Preprint. Discussion started: 17 August 2021

(c) Author(s) 2021. CC BY 4.0 License.

(c) (i)

Porada, P., Lenton, T. M., Pohl, A., Weber, B., Mander, L., Donnadieu, Y., Beer, C., Po, U. and Kleidon, A.: High potential for weathering and climate effects of non-vascular vegetation in the Late Ordovician ", Nat. Commun., 1-13, doi:10.1038/ncomms12113, 2016.

Reuter, R. J. and Bell, J. C.: Soils and Hydrology of a Wet-Sandy Catena in East-Central Minnesota, Soil Sci. Soc. Am. J., 65(5), 1559-1569, doi:10.2136/sssaj2001.6551559x, 2001.

Riebe, C. S., Kirchner, J. W., Granger, D. E. and Finkel, R. C.: Strong tectonic and weak climatic control of long-term chemical weathering rates, Geol. Soc. Am., 29(6), 511-514, 2001.

540 Riebe, C. S., Kirchner, J. W. and Finkel, R. C.: Erosional and climatic effects on long-term chemical weathering rates in granitic landscapes spanning diverse climate regimes, Earth Planet. Sci. Lett., 224, 547-562, doi:10.1016/j.epsl.2004.05.019, 2004.

Román-Sánchez, A., Vanwalleghem, T., Peña, A., Laguna, A. and Giráldez, J. V.: Controls on soil carbon storage from topography and vegetation in a rocky, semi-arid landscapes, Geoderma, 311, 159-166, doi:10.1016/j.geoderma.2016.10.013, 5452018.

Román-Sánchez, A., Reimann, T., Wallinga, J. and Vanwalleghem, T.: Bioturbation and erosion rates along the soil-hillslope conveyor belt, part 1: Insights from single-grain feldspar luminescence, Earth Surf. Process. Landforms, 44(10), 2051-2065, doi:10.1002/esp.4628, 2019.

Salve, R., Rempe, D. M. and Dietrich, W. E.: Rain, rock moisture dynamics, and the rapid response of perched groundwater in weathered, fractured argillite underlying a steep hillslope, Water Resour. Res., 48(11), 1-25, doi:10.1029/2012WR012583, 2012 .

Samouëlian, A. and Cornu, S.: Modelling the formation and evolution of soils, towards an initial synthesis, Geoderma, 145(34), 401-409, doi:10.1016/j.geoderma.2008.01.016, 2008.

Schaller, M. and Ehlers, T. A.: Vegetation and climate effects on soil production, chemical weathering, and physical erosion rates, Earth Surf. Dyn., (April), 1-26, 2021.

Schoonejans, J., Vanacker, V., Opfergelt, S., Ameijeiras-Mariño, Y. and Christl, M.: Kinetically limited weathering at low denudation rates in semiarid climatic conditions, J. Geophys. Res. Earth Surf., 336-350, doi:10.1002/ 2015JF003626, 2016.

Temme, A. J. A. M. and Vanwalleghem, T.: LORICA - A new model for linking landscape and soil profile evolution: Development and sensitivity analysis, Comput. Geosci., 90, 131-143, doi:10.1016/j.cageo.2015.08.004, 2016.

560 Vanwalleghem, T., Stockmann, U., Minasny, B. and McBratney, A. B.: A quantitative model for integrating landscape evolution and soil formation, J. Geophys. Res. Earth Surf., 118(2), 331-347, doi:10.1029/2011JF002296, 2013.

Welivitiya, W. D. D. P., Willgoose, G. R. and Hancock, G. R.: A coupled soilscape-landform evolution model: Model formulation and initial results, Earth Surf. Dyn., 7(2), 591-607, doi:10.5194/esurf-7-591-2019, 2019.

Yoo, K., Amundson, R., Heimsath, A. M., Dietrich, W. E. and Brimhall, G. H.: Integration of geochemical mass balance with 565 sediment transport to calculate rates of soil chemical weathering and transport on hillslopes, J. Geophys. Res., 112, doi:10.1029/2005JF000402, 2007. 
https://doi.org/10.5194/soil-2021-78

Preprint. Discussion started: 17 August 2021

(C) Author(s) 2021. CC BY 4.0 License.

(c) (1)

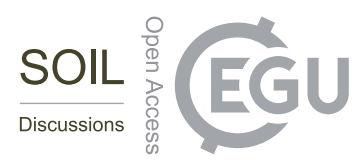

Yoo, K., Mudd, S. M., Sanderman, J., Amundson, R. and Blum, A.: Spatial patterns and controls of soil chemical weathering rates along a transient hillslope, Earth Planet. Sci. Lett., 288(1-2), 184-193, doi:10.1016/j.eps1.2009.09.021, 2009.

Yoo, K., Weinman, B., Mudd, S. M., Hurst, M., Attal, M. and Maher, K.: Evolution of hillslope soils: The geomorphic theater 570 and the geochemical play, Appl. Geochemistry, 26(SUPPL.), 149-153, doi:10.1016/j.apgeochem.2011.03.054, 2011. 